\title{
TURISTINIŲ ŽEMĖLAPIŲ ŽENKLŲ SISTEMŲ PRAGMATINIS ASPEKTAS: ŽENKLŲ ATPAŽINIMAS
}

\author{
Giedrẻ Beconytè ${ }^{1}$, Jurga Špūraitė ${ }^{2}$ \\ ${ }^{1}$ Vilniaus universitetas, M. K. Čiurlionio g. 21/27, LT-03101 Vilnius-9, el. paštas: giedre.beconyte@ gf.vu.lt, \\ ${ }^{2}$ Geologijos ir geografijos institutas, T. Ševčenkos g. 13, LT-03223 Vilnius-6, el. paštas: jurga@geo.lt
}

Iteikta 20031011 , priimta 20040210

\begin{abstract}
Santrauka. Lietuvoje išleidžiama daug ir ịvairios teminès kartografinès produkcijos. Ypač didelę teminių žemèlapių dali sudaro îvairi turistinè kartografinè medžiaga. Nors jos paklausa didelè, tačiau informacijos perdavimo kokybè toli gražu ne visada esti nepriekaištinga. Sudarant ženklų sistemas kol kas mažai galvojama apie būsimą žemėlapio naudotoją bei kaip pateikti informaciją, kad žemėlapio ženklai būtų informatyvūs, greitai bei teisingai suvokiami vizualiai ir gerai įsimenami. Lietuvoje kartografinių tyrimų ženklų suvokimo problemoms spręsti iki šiol nebuvo atliekama. Straipsnyje bandoma nubrèžti svarbiausias turistinių žemėlapių pragmatikos tyrimų kryptis pagal naudotojų grupes ir ženklų ypatybes. Aprašomas pirmasis bandymas tirti žemėlapiuose naudojamų ženklų atpažinimo ypatumus. Rezultatai leidžia teigti: ikoninio sutartinio ženklo panašumas i̇ žymimą objektą ir raiškumas negarantuoja, kad toks ženklas issimenamas lengviau. Geriausiai atpažǐstami tekstiniai ir simboliniai ženklai; be to, vyrai ir moterys ženklus atpažista skirtingai. Remiantis tyrimo rezultatais pateikta rekomendacijų turistinių žemèlapių sudarytojams.
\end{abstract}

Raktažodžiai: sutartiniai ženklai, teminė kartografija, turistiniai žemėlapiai, vizualizavimas, ženklų semiotinè analizè, vizualinis suvokimas, atpažinimo testai.

\section{Ivadas}

Turistinès kartografinès produkcijos pasiūla Lietuvos rinkoje intensyviai didèti pradejo atkūrus nepriklausomybę. Pagerèjus socialinèms bei ekonominėms sąlygoms, „atsidarius“ sienoms, Lietuvoje sparčiai pradèta plètoti turizma, ir tai tapo vienu iš pagrindiniu veiksnių, lemusių turistinès kartografinès produkcijos ivvairiapusę plètrą. Turistams skirta kartografinè produkcija pateikiama spausdinta žemèlapių galima issigyti degalinèse, turizmo informacijos centruose, parduotuvèse, rasti žurnaluose, bukletuose arba skaitmeniniu pavidalu - kol kas tai informacija, randama internete, tačiau galima tikètis, kad netrukus bent dalis jos bus kiekvienam prieinama mobiliojo irenginio ekrane. Padidèjo ne tik bendrujų turistinių žemèlapių poreikis, bet ir susidomèjimas specializuota kartografine produkcija, skirta turistu grupèms, propaguojančioms konkrečią turizmo rūší.

Skirtingose leidybos istaigose išleistoje turistinèje kartografinèje produkcijoje teminè informacija vizualizuota nevienodai. Universaliuose (pavyzdžiui, keliu) žemėlapiuose ženklai daugiau ar mažiau standartizuoti, o specializuotuose žemėlapiuose, ypač kuriu funkcija reklaminè, kone kiekvienas leidèjas naudoja savo parinktus ar sukurtus ženklus. Sudarant tokias ženklų sistemas retai galvojama apie būsimą žemèlapio naudotoją, kaip jam pateikti informacija, kad žemèlapio ženklai būtŭ informatyvūs, greitai bei teisingai atpažistami ir analizuojami vizualiai. Ženklai dažnai būna sudètingi, daugiareikšmiai arba blogai atspindi žymimą objektą. Nevienodas tụ pačių objektų žymėjimas arba tie patys ženklai skirtingiems objektams žymèti klaidina naudoją ir labai apsunkina žemèlapio skaitymą.

Norètume atkreipti profesionalių kartografų dėmesi i tai, kad teminę informaciją būtina pateikti taip, kad ją suprastų ne tik žemèlapio kūrejjas, bet ir jo naudotojas, kad ženklai būtu vienareikšmiai, lengvai skaitomi, greitai atpažistami ir ilgam issimenami - dažniausiai turistinių žemèlapių naudotojai nèra linke gilintis $i \mathrm{ju}$ legendas. Straipsnyje klasifikuojami turistiniai žemèlapiai ir nubrèžiamos pagrindinès tyrimų kryptys, siekiant pagal pragmatikos principus sukurti metodologini pagrindą informacijai vizualizuoti turistiniuose ir turistiniuose-reklaminiuose žemèlapiuose, be to, aprašytas vienas konkretus tokio pobūdžio tyrimas ir jo rezultatai.

\section{Turistinių žemėlapių specifika}

\subsection{Turistinių žemėlapių tipai}

Kartografinių kūrinių gamyba labai susijusi su turizmo plètra:

a) didejja tradicinių turistinių žemèlapių paklausa;

b) kuriasi nauju tipu bei specialioms naudotoju grupèms skirtų turistinių žemèlapių rinka;

c) kartografams tenka ieškoti nauju, originalių informacijos perteikimo žemėlapyje būdų;

d) kyla poreikis turistinius žemèlapius publikuoti ivairiomis kalbomis;

e) gausejja elektroninės kartografinès produkcijos. 
Ši sąsaja nèra vienpusè. Lengvai prieinami ir kokybiški žemèlapiai gali turèti didelès ịtakos nukreipiant turistų srautą i norimą vietą, reklamuojant pavienius objektus ar paslaugas. Gerai parengti, patrauklūs žemèlapiai savaime daro gerą ìspūdi apie vietovę, ir atvirkščiai - painūs, neestetiški ar, dar blogiau, netikslūs žemèlapiai gali atgrasinti potencialius turistus.

Turistinę kartografinę produkciją galima klasifikuoti pagal jos specializacijos laipsni. Universaliuose, su vietove susipažinti ir joje orientuotis naudojamuose žemėlapiuose, visi objektai vienodai svarbūs, ir né viena ženklu kategorija specialiai neakcentuojama. Specializuotieji žemèlapiai skirti mažesnèms naudotoju grupèms, juose akcentuojami maršrutai ir pateikiami (arba išskiriami) tik tam tikros rūšies objektai. Pavyzdys - reklaminiai žemélapiai, kurie iš esmès yra tik fonas vienam ar keliems reklamuojamiems objektams. Nuo turistinio žemèlapio specializacijos laipsnio dažnai priklauso, kokio tipo ikoniniai sutartiniai ženklai jame naudojami abstraktūs geometriniai ar vaizdūs - perspektyviniai. Tačiau pastebima tendencija net ir universaliuose žemèlapiuose dažniau naudoti ryškius, i̇ žymimą objektą panašius, patrauklius ženklus.

\subsection{Sutartinių ženklų tipai pagal asociatyvumą}

Žemėlapio informacijos perdavimo (komunikacinis) procesas vyksta tokia seka: reiškinio kartografavimas - duomenys apie ji, kartografo (žemèlapio kūrèjo) duomenų interpretavimas - sukurtas žemèlapis - žemèlapio naudotojo informacijos interpretavimas.

Kai skaitome arba klausome skaitomo teksto, informacija gaunama nuosekliai, t. y. žodžiai seka vienas po kito eilès tvarka. Taigi esame tarsi „užprogramuoti“ priimti minčiu srautą tam tikra apibrežta tvarka. Vaizdinè informacija suvokiama kitaip. Optinis vaizdų îspūdis sinoptiškas (t. y. viskas vienu metu), o ne nuoseklus. Kiekvienas žemèlapio ženklas suvokiamas atitinkamai pagal jo padèti ir raiškumą, tarpusavyje siejant ir visus kitus žemèlapyje esančius ženklus. Kuriant žemèlapi negalima sisteminti informacijos nuosekliai kaip kalbant ar rašant, privalome visuomet galvoti apie žemėlapi kaip apie visuma.

Girdèdami garsų arba žodžiu seką automatiškai bandome juos suprasti. Nesąmoningai tai darome ir su vaizdais. Kadangi žmonès linkę atmesti vizualu monotoniškumą ir neaiškumą, vaizdas sisteminamas taip, kad jo grafiniai atributai turètu tam tikrą prasmę. Kiekvieną ženklą skaitytojas skiria pagal reikšmę bei grafinius atributus, tokius kaip: dydis, forma ar spalva, interpretuoja ženklų raišką, išdèstymą, klasifikavimą.

Taigi skaitytojas grafinius vaizdus mato struktūriškai. Kai kurie ženklai atrodo svarbesni už kitus, kai kurios formos išsiskiria, dominuoja tam tikros spalvos ir pan. Jei šios vizualios sąsajos ir kartografo, ir žemèlapio naudotojo bus suvokiamos vienodai, vyks efektyvi komunikacija. Jei ne, žemèlapio modelis greičiausiai bus nevykęs.

Šiuolaikinèje semiotikoje ženklas apibrèžiamas kaip materialus, jutimo organais suvokiamas objektas pažinimo ir bendravimo procese, naudojamas informacijai suvokti, saugoti, perduoti, interpretuoti [1].

Sutartiniai ženklai - pagrindinè savybè, skirianti žemèlapi nuo daugelio kitu geografiniu modeliu, tokiu kaip: kosminès nuotraukos, panoramos, peizažai. Ženklai žemèlapyje - tai rega priimami vaizdavimo elementai, jais sąlygiškai ir apibendrintai pristatomi mus supančio pasaulio procesai ir reiškiniai, ju vieta, kiekybinès ir kokybinès charakteristikos, struktūra, dinamika ir t. t. [2].

Pagrindinès žemėlapyje naudojamų ženklų funkcijos - komunikacine, t. y. tam tikros informacijos apie objektą perdavimas žemèlapio kūrèjo žemèlapio skaitytojui, ir pažintiné - naujų žinių gavimas „skaitant" kartografuotą objektą.

Atliekant tyrimą, ženklo panašumui su žymimu objektu apibrēžti vartojamas terminas asociatyvumo laipsnis. Asociatyvumo laipsnis apibrěžia ženklo sąsają su žymimu objektu pagal tai, kaip realaus objekto ar jo simbolio savybes atspindi. Ženklo informatyvumas paprastai nusakomas ženklu perduodamos informacijos objekto atributu gausa.

Išanalizavus turistiniuose žemėlapiuose naudojamus ženklus bei remiantis literatūros šaltiniais, kuriuose pateikiamos ịvairios ženklu klasifikacijos [26], sudaryta turistiniuose žemèlapiuose naudojamu ženklų klasifikacija pagal piešinio struktūrą ir semantinį ryši su žymimuoju objektu* (1 pav.):

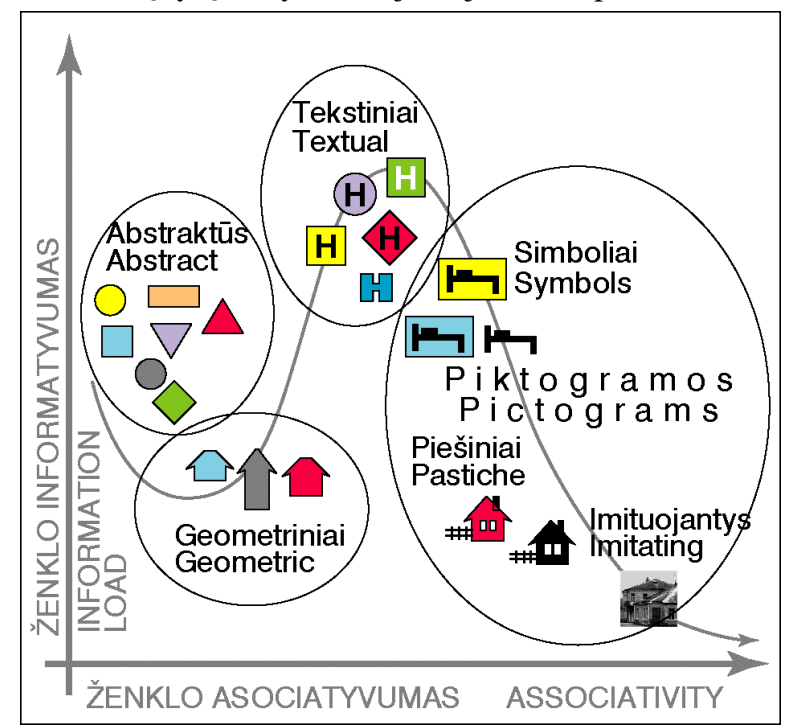

1 pav. Ikoninių ženklų asociatyvumas ir potencialus informatyvumas

Fig. 1. Associativity and potential information load of icon signs

\footnotetext{
* Išskirtos ženklų grupès žymėjimas iš dalies sutampa, todèl tai nera tikra klasifikacija, o tik tipu eilè, sutvarkyta pagal panašumą i žymimaji objektą.
} 
1. Abstraktieji ženklai - tai ženklai iš abstrakčių geometrinių figūrų.

2. Geometriniai ženklai - iš geometrinių elementų, forma šiek tiek primenančių žymimą objektą, sudaryti ženklai.

3. Tekstiniai ženklai. Jų pagrindas - tekstinis simbolis.

4. Ženklai-simboliai. Dažniausiai tai žymimo objekto metafora, t. y. nepanašūs į objektą.

5. Piešinio tipo ženklai - pakankamai panašūs i žymimą objektą.

6. Imituojantys ženklai. Reklaminiuose žemèlapiuose neretai naudojamos nuotraukos, pavyzdžiui, viešbutis žymimas ne sutartiniu ženklu, bet fasado nuotrauka, trimačiu piešiniu ir pan. Fotorealistinis ženklas suvokiamas specifiškai, be to, atpažinimas priklauso daugiausiai nuo to, ar respondentui objektas jau yra žinomas, todèl atliekant tyrimą tokio tipo ženklai nenaudoti.

Paskutinių trijų tipų ženklai dar vadinami piktogramomis.

\subsection{Turistinių žemėlapių sutartinių ženklų ypatumai}

Turistiniams žemėlapiams būdinga tai, kad pragmatinis jų kokybės aspektas naudotojams reikšmingesnis negu daugumos kitų teminių žemèlapių. Ženklų patogumas skaityti ir suprasti - vienas svarbiausiu kriteriju, pagal kuri naudotojas vertina žemėlapi. Be to, turistinius žemėlapius naudoja daug Ł̇vairiu visuomenès grupių, kurių reikalavimai tam pačiam žemèlapiui ir jo kokybès vertinimas skirtingi. Būtent turistiniai žemèlapiai yra pirmieji teminiai žemèlapiai, vis aktyviau naudojami mobiliuosiuose irenginiuose, taigi nuo jų kokybės apskritai gali priklausyti „mobiliosios“ kartografijos perspektyvos.

Kalbant apie ikoninius ženklus bendruosiuose turistiniuose žemèlapiuose naudotojui ypač svarbu:

- atpažinti naujus ženklus nesinaudojant legenda;

- gerai i̇siminti atpažintus ženklus;

- greitai atpažinti idomias vietas ar maršrutus pagal ženklu grupes;

- $\quad k a d$ ženklai netrukdytų skaityti bendrosios žemėlapio informacijos ir atvirkščiai.

Dèl dviejų turistinių žemėlapių funkcijų orientavimo ir reklamos - bei poreikio išlaikyti pusiausvyrą tarp jų tokių žemėlapių ženklams keliama daugiau reikalavimu ir šiuos ženklus kur kas sunkiau standartizuoti negu kitų teminių žemėlapių.

Turistinių žemėlapių ženklų sistemos paprastai esti sudètingos. Joms būdinga:

- daug vieno tipo ženklų;

- daug skirtingǔ ženklų tipų;

- $\quad$ skirtingi ženklai vienodai svarbūs;
- tie patys ženklai sudaro hierarchijas pagal skirtingus požymius;

- $\quad$ ženklai mažai standartizuoti;

- Ženklai keičiami atsižvelgiant í žemèlapio paskirtí, kontekstą ar konjunktūrą;

- nèra semantinio generalizavimo tradicijos;

- ne visada tikslios ženklų koordinatès, juos galima išdèstyti skirtingos konfigūracijos grupèmis;

- $\quad$ elektroniniuose žemėlapiuose ženklai turi būti aktyvūs objektai.

\section{3. Ženklų pragmatikos tyrimų kryptys}

Norint ištirti žemėlapio suvokimo procesus ir mechanizmus keliami du pagrindiniai uždaviniai:

- sudaryti metodiką skirtingiems procesų lygiams - pavienių ženklų, jų grupių, bendrojo kartografinio vaizdo suvokimui tirti;

- ivertinti tyrimo rezultatus.

Pavienių ženklų vizualinio suvokimo tyrimų linkmè dideli eksperimentai ir kartografineje, ir psichologineje plotmèje. Tai grafinių priemonių efektyvumo, pavyzdžiui, geometrinių figūrų, besiskiriančių savo forma, suvokimo tyrimas; kartografinių ženklų ir šriftų parinkimo; spalvinès gamos skirtumų vertinimas; ženklų grupèse suvokimas ir kt.

Tiriama dviem būdais:

1. Pavienių ženklų ar nesusijusių ženklų grupès (ne žemèlapyje, neatsižvelgiant $\mathfrak{i}$ objektų erdvinius ryšius) suvokimas.

2. Skaitomumo ir pavienių ženklų atpažinimo realiame žemèlapyje pagal skirtingus spalvinius tonus, sanklotas, linijinius bei arealinius žymèjimus analizė [1].

Skiriami keliu tipu svarbiausi bendrieji klausimai, i kuriuos reikia atsakyti, numatant reikalingu turistiniu žemèlapių pragmatikos tyrimu kryptis*. Tai klausimai, susiję su:

- informacijos adresatu (žemėlapio naudotoju) - kaip žmonès suvokia vaizdinę žemèlapio informaciją ir ją isisavina, kaip ta informacija tampa žiniomis, ko naudotojams reikia;

- technine iranga - kaip geriau panaudoti nauju technologijų teikiamas galimybes;

- vaizdu žemèlapyje: jis gali būti dvimatis ar trimatis, statiškas ar interaktyvus, kintantis laike arba ne ir pan.;

- informacija: duomenys, metaduomenys, kontekstas, kuriame žemėlapio informacija greičiau ir geriau suprantama bei naudojama;

Laikysime, kad ženklų sistemos yra semiotiškai taisyklingos, o visi keliami klausimai susiję vien su pragmatiniu aspektu. 
- $\quad$ kontekstu (aplinka): kokius iš daugybès realiai egzistuojančių objektu galima ir reikia vaizduoti žemèlapyje.

Kalbant apie pavienius ženklus, svarbiausi yra pirmosios ir trečiosios grupès klausimai. 2 paveiksle parodytos bendros ženklų pragmatikos tyrimų sritys (elektroninių žemėlapu - ir ketvirtoji sritis - skirtingos žemèlapio perdavimo priemonès).

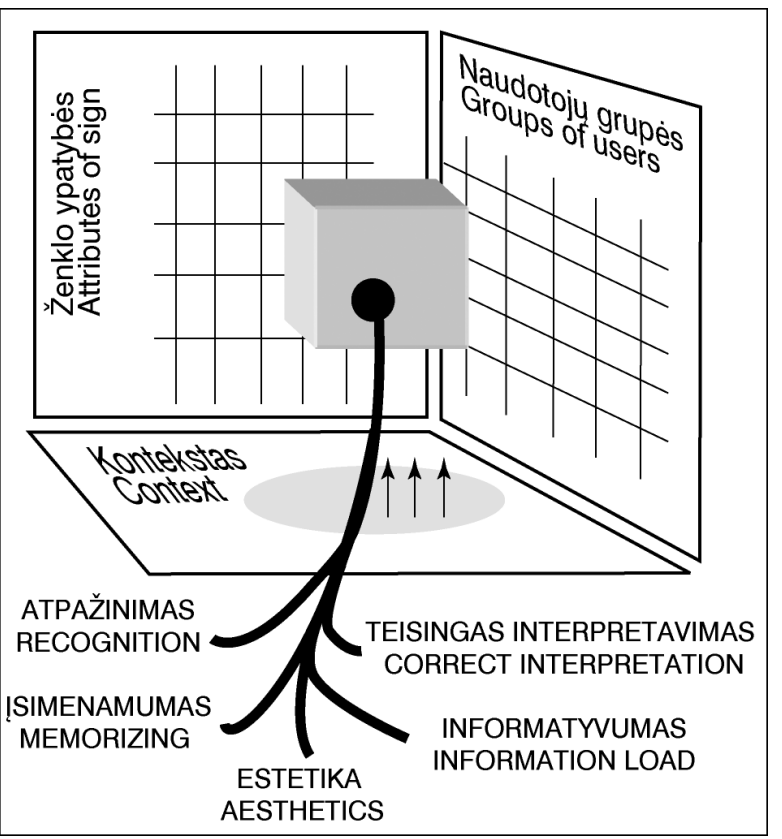

2 pav. Ikoninių ženklų pragmatikos tyrimų kryptys

Fig 2. Structure of investigation into pragmatics of icon signs

Naudotoju grupės žemèlapius naudoja skirtingiems tikslams ir skirtingai ženklus suvokia. Galima išskirti ne tik ivvairių tipų turistus, bet ir grupes pagal amžių, lyti, išsilavinimą bei neigaliuosius. Didelès reikšmès turi gimtoji kalba ir kultūra, nuo to labai priklauso, kaip suvokiami ir interpretuojami žemèlapio ženklai, todèl, sudarant žemèlapius skirtingomis kalbomis, turètų būti verčiami ne tik vietovardžiai ar tekstai, bet ir grafinių simboliu paaiškinimai.

Svarbiausios grafinès ženklo savybès, nuo kurių priklauso jo funkcionalumas, yra grafinè struktūra (sudètingumas ir panašumas i žymimą objektą), informatyvumas (semantiškai susietų atributų skaičius) ir kontrastiškumas, dažniausiai priklausantis nuo ženklo dydžio ir spalvų. Papildomai dèmesi reiktų skirti elektroninių žemėlapių ženklų animavimui ir reaktyvumui (gebai reaguoti i naudotojo veiksmus), užtikrinti, dažniausiai pateikiant papildomos informacijos apie žymimą objektą.

Kiekvieno ženklo prieinamumui ir suvokimo spartai neabejotinai itakos turi jo kontekstas - kiti ženklai, žemèlapyje vizualiai išskiriamos objektų grupès ir bendras fonas. Elektroniniuose žemèlapiuose reikšmingi ir žemėlapio ar konkretaus ženklo naudojimo scenarijai.

\section{Turistinių žemėlapių ženklų atpažinimo tyrimas}

\subsection{Hipotezė apie skirtingų tipų ženklų atpažinimą}

Visose komunikacinio proceso stadijose esti įvairių perduodamą informaciją iškreipiančių veiksnių, kuriuos būtų galima ívardyti kaip „trukdžius“ [7]. Galima spèti, kad dalis jų yra užkoduota ir paties ženklo struktūroje.

Laikantis vyraujančios ir gana logiškos nuostatos galima būtų tarti, kad ženklų issimenamumas tiesiogiai priklauso nuo jų panašumo i žymimaji objektą ir, pereinant nuo abstraktaus ženklo iki piešinio formos, tolygiai gerèja. Abstraktūs ženklai issimenami blogiausiai, kitų tipų ženklai - tuo geriau, kuo daugiau asocijuojasi su žymimuoju objektu, o geriausiai turètų būti įsimenami pieštiniai ženklai. Tačiau kuo ženklas panašesnis i žymimą objektą (dažnai net i konkretų pastata), tuo daugiau grafinių jo atributu panaudojama tam panašumui sukurti. Taigi lieka mažiau galimybių ženklu perteikti nevizualiają informaciją apie objektą.

Atsižvelgiant i du parametrus (1 pav.), optimalus informatyvumo ir asociatyvumo santykis būdingas ne piešiniams, o tekstiniams ir grafiniams simboliams. Todèl darème prielaidą, kad grafinès formos paprastumas ir papildoma ženklu perduodama informacija leidžia greičiau ir tiksliau atpažinti anksčiau matytą ženklą ir yra svarbesni už tiesioginę asociaciją su vaizduojamu objektu.

Siekiant patikrinti šią ženklų suvokimo hipotezę ir išsiaiškinti, kokios apskritai yra ženklų atpažinimo tendencijos, buvo atliktas turistiniuose žemèlapiuose dažnai pasitaikančių ženklų tyrimas.

\subsection{Tyrimo tikslas ir metodika}

Vilniaus universitete atlikto tyrimo tikslas buvo ištirti turistinių žemėlapių ženklus, tam tikros žemèlapių naudotojų grupès jų atpažinimo ypatybes. Taikyta loginiai tyrimo metodai, sociologinė anketinè turistiniu žemèlapių naudotojų apklausa, matematinè rezultatú analizè.

Atliekant bendrujų turistinių žemėlapių ženklų atpažinimo tyrimą apklausai buvo pasirinkta 50 respondentų - šios sąlygos svarbu laikytis tada, kai tyrimo rezultatai išreiškiami procentais (apskritai minimalus tiriamų atvejų skaičius turi būti ne mažesnis kaip 30).

Imties tūriui parinkti buvo taikomas atsitiktinès imties metodas. Apklausoje dalyvavo respondentai, kurie palyginti dažnai naudojasi turistiniais žemèlapiais. Laikytasi principo, kad pasirinktosios tiriamuju grupès savybès turi būti tokios pat, kaip ir visos populiacijos [8]. Pasirinktą populiaciją sudaro darbingo amžiaus žmonès, taigi i imti proporcingai pateko 24 vyrai ir 26 moterys. (Lietuvoje, pagal Lietuvos statistikos metrašti (2000), 1000 vyrų tenka 1121 moteris.

Anketinèje apklausoje respondentams pateikti penki bendrojo pobūdžio klausimai (apie amžių, lytị, išsilavinimą, naudojimąsi žemėlapiais) ir 40 skirtingu 
tipu turistiniuose žemėlapiuose dažnai pasitaikančių ikoninių ženklų. Respondentams per 10 minučių reikejjo ịrašyti spejjamas ženklų reikšmes.

Tyrimu siekta nustatyti:

- turistiniuose žemėlapiuose naudojamų ženklų bendraji pažinumą;

- kaip visi respondentai atpažista skirtingo tipo ženklus;

- kaip ženklus atpažista vyrai ir moterys;

- kaip vyrai ir moterys atpažizsta skirtingo tipo ženklus;

- kaip skirtingo amžiaus respondentai atpažįsta skirtingo tipo ženklus.

Rezultatai buvo apdoroti statistiniais metodais atlikta variacinè analizè (ANOVA testas, LSD post hoc kriteriju testas) ir klasterinè duomenų analizè (hierarchinis metodas) [9].

Klasteriuose atstumams skaičiuoti (tarp tiriamų ženklų grupiu) pasirinktas kvadratinès Euklido metrikos ir Ward'o metodas.

\subsection{Rezultatų analizė}

Surinktiems duomenims taikant ANOVA testą, ivertinta, ar reikšmingai skiriasi visų ženklų grupių vidurkiai, atpažistant ženklus pagal padarytų klaidų skaičių (dažni). Nustatyta, kad visos ženklų grupès pagal padarytų klaidų kieki statistiškai reikšmingai skiriasi $(\mathrm{p}<0,001)$.

Atlikus $L S D$ post-hoc kriterijų testą, ivvertinta, kiek patikimai pagal padarytų klaidų skaičių kiekviena ženklų grupè statistiškai reikšmingai skiriasi nuo kitų ženklų grupių (1 lentelè).

1 lentelè. Ženklų grupių skyrimo statistinis patikimumas, \% Table 1. Reliability of difference between the groups of signs, $\%$

\begin{tabular}{|c|c|c|c|c|c|}
\hline $\begin{array}{l}\text { Ženklai } \\
\text { Signs }\end{array}$ & 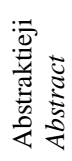 & 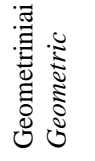 & 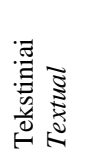 & 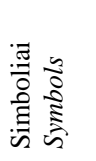 & 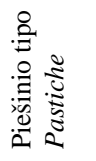 \\
\hline $\begin{array}{r}\text { Abstraktieji } \\
\text { Abstract }\end{array}$ & - & $>99,99$ & $>99,99$ & $>99,99$ & $>99,99$ \\
\hline $\begin{array}{r}\text { Geometriniai } \\
\text { Geometric }\end{array}$ & & - & $>99,99$ & $>99,99$ & $>99,99$ \\
\hline $\begin{array}{r}\text { Tekstiniai } \\
\text { Textual }\end{array}$ & & & - & 99,99 & $>99,99$ \\
\hline $\begin{array}{r}\text { Simboliai } \\
\text { Symbols }\end{array}$ & & & & - & $>99,99$ \\
\hline $\begin{array}{r}\text { Piešinio tipo } \\
\text { Pastiche }\end{array}$ & & & & & - \\
\hline
\end{tabular}

Iš gautų rezultatų matome, kad klaidos tikimybė visų tiriamų ženklų grupių statistiškai patikimai skiriasi ( $\mathrm{p}<0,001)$.

Apskaičiuotas kiekvienos ženklų grupès neatpažintų ženklų procentas (3 pav.). Kaip ir buvo prognozuota, geometrinius ir nelabai vaizdžius ženklus apklaustieji respondentai atpažista blogiausiai.

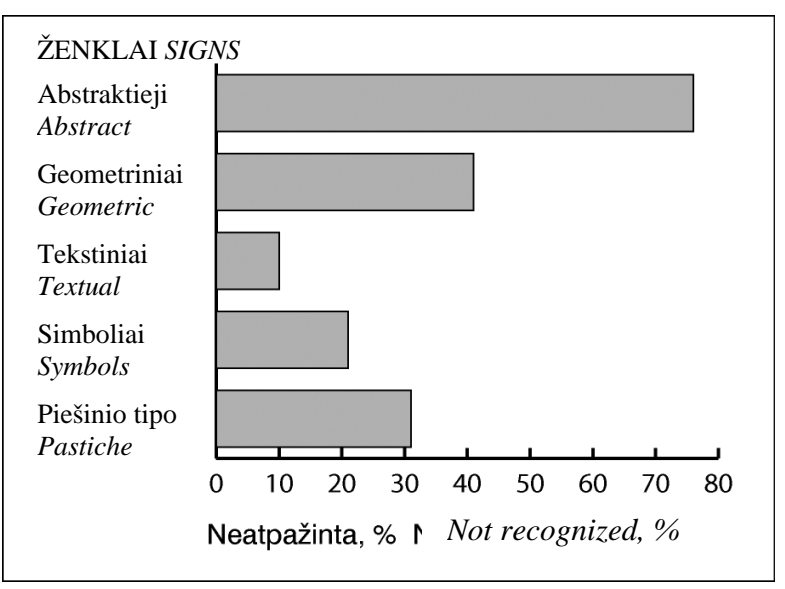

3 pav. Klaidų skaičius procentais atpažįstant skirtingų tipu ženklus

Fig 3. Percentage of errors in recognition of different sign types

Apskaičiuota ir kaip atpažista ženklus vyrai ir moterys bei skirtingo amžiaus žmonès atskirai. Pagal amžių išskirtos dvi respondentų grupès: $16-40$ ir 40-60 metų (kaip jau minèta, visa populiacija - darbingo amžiaus žmonès).

Atlikus skirtingu lyčių $L S D$ post hoc kriterijų testą, gauta, jog skirtingus ženklų tipus vyrai ir moterys atpažista skirtingai, patikimas skirtumas $-\mathrm{p}<0,001$. Analizuojant, kaip skirtingų lyčių atstovai atpažįsta ženklų grupes, gauti duomenys bus statistiškai patikimi. Taip pat apskaičiuotas skirtingų lyčių atstovų ženklų atpažinimo klaidos vidurkis. Moterys atpažindamos ženklus vidutiniškai padare $28 \%$, vyrai $-34 \%$ klaidų.

Taikant tuos pačius metodus, atliktas bendrasis vertinimas, kaip ženklus atpažista skirtingos lyties ir amžiaus grupių respondentai (4 pav.).

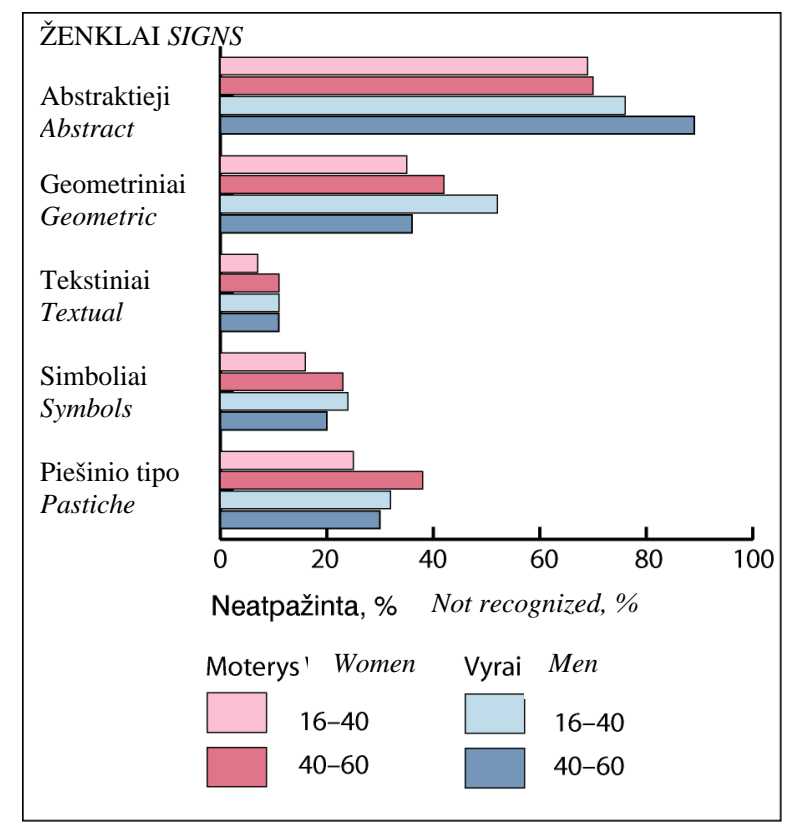

4 pav. Padarytų klaidų skaičius (procentais) pagal respondentų grupes, atpažįstant visų tipų ženklus

Fig 4. Percentage of errors in recognition of different sign types by different groups of respondents 
Statistiškai patikimo skirtumo tarp respondentų pagal amžiaus grupes nèra $(p=0,161)$. Klaidingai atpažinti ženklai: 16-40 metų - 30\%; 40-60 metų $33 \%$.

LSD post hoc kriterijų testas taikytas skaičiuojant kiekvienos ženklų grupès atpažinimo procentą atskirai skirtingu lyties bei amžiaus grupių. Rezultatai pateikiami 2 lentelèje.

2 lentelė. Respondentų grupių padarytos klaidos pagal ženklų tipa

Table 2. Percentage of errors by different respondent groups across different sign types

\begin{tabular}{|r|r|c|c|c|c|}
\hline \multirow{2}{*}{$\begin{array}{r}\text { Lytis Sex } \\
\text { Amžius Age }\end{array}$} & \multicolumn{2}{|c|}{ Neatpažinta, \% Not recognized, \% } \\
\cline { 2 - 6 } & \multicolumn{2}{|c|}{ Moterys Women } & \multicolumn{2}{|c|}{ Vyrai Men } \\
\cline { 2 - 6 } & $16-40 \mathrm{~m}$. & $40-60 \mathrm{~m}$. & $16-40 \mathrm{~m}$. & $40-60 \mathrm{~m}$. \\
\hline \multirow{4}{*}{$\begin{array}{r}\text { Abstraktieji } \\
\text { Abstract }\end{array}$} & 69 & 70 & 76 & 89 \\
\cline { 2 - 6 } & $\begin{array}{r}\text { Geometriniai } \\
\text { Geometric }\end{array}$ & 35 & 42 & 52 & 36 \\
\cline { 2 - 6 } & $\begin{array}{r}\text { Tekstiniai } \\
\text { Textual }\end{array}$ & 7 & 11 & 11 & 11 \\
\cline { 2 - 6 } & $\begin{array}{r}\text { Simboliai } \\
\text { Symbols }\end{array}$ & 16 & 23 & 24 & 20 \\
\cline { 2 - 6 } & $\begin{array}{r}\text { Piešinio tipo } \\
\text { Pastiche }\end{array}$ & 25 & 38 & 32 & 30 \\
\hline
\end{tabular}

Tiriant ženklų tipus pagal tai, kaip juos atpažissta skirtingos respondentu grupès, atlikta klasterinè analizè. Gauti rezultatai pateikiami 5 paveiksle. Aptariant skaičiavimo rezultatus, pagal atpažinimo laipsni panašiausiai atpažistami tekstiniai ir piešinio tipo ženklai, taip pat ženklai-simboliai.

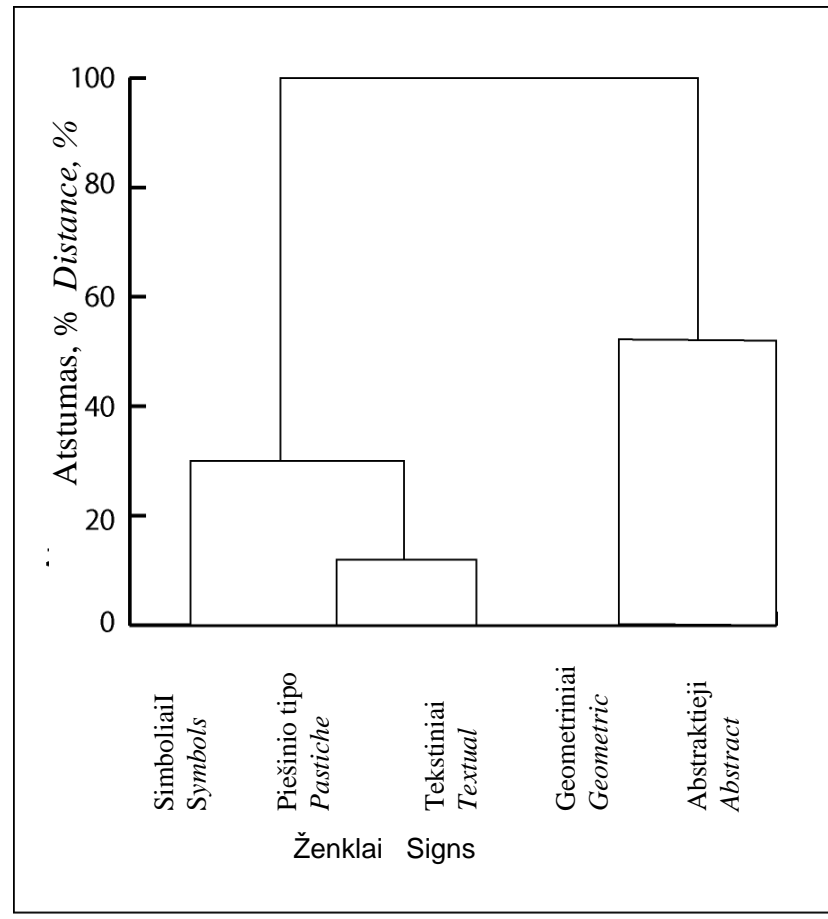

5 pav. Ženklų tipų atpažinimo rezultatų panašumas vertinant skirtingas respondentu grupes

Fig 5. Similarity of sign types by recognition in different respondent groups
Atskirą grupę (klasteri) sudaro blogiausiai atpažistami abstraktieji ir geometriniai ženklai.

Ištyrę, vyrų ir moterų ženklų atpažinimo rezultatus, atlikę klasterinę analizę matome, kad moterų, atpažinusių ženklus, skaičius pasiskirste panašiai kaip ir bendrame ženklų grupių atpažinimo klasteryje (5 pav.). Skiriasi tik skirtumai tarp ženklų grupių. Pagal respondentų vyrų rezultatus panašiausiai atpažistami tekstiniai ženklai ir simboliai, taip pat piešiniai, o abstraktūs ir geometriniai ženklai, kaip ir bendruoju atveju, priskiriami atskiram, nuo pirmosios grupès tolesniam, klasteriui.

Bendrasis ženklų atpažinimas pagal respondentų grupes: panašiausiai ženklus atpažista abiejų amžiaus grupių vyrai, nuo jų nelabai nutolusi 16-40 metų moteru grupè. Savičiausia grupè pagal ženklų atpažinimą yra 40-60 metų moterys.

\subsection{Rezultatu vertinimas}

Tyrimo pradžioje buvo suformuluotos dvi hipotezès:

1. Pavienių ženklų atpažinimo rezultatai tiesiogiai proporcingi jų asociacijos su žymimuoju objektu stiprumui.

2. Geriausiai isimenami ir atpažįstami paprastos struktūros ženklai, kurie nèra tiesiogiai panašūs i žymimus objektus, bet su jais asocijuojasi; nuo tam tikros ribos dèl panašumo i žymimą objektą ženklo isimenamumas tik pablogèja.

Šios hipotezès ir tyrimo metu gauti rezultatai parodyti 6 paveiksle.

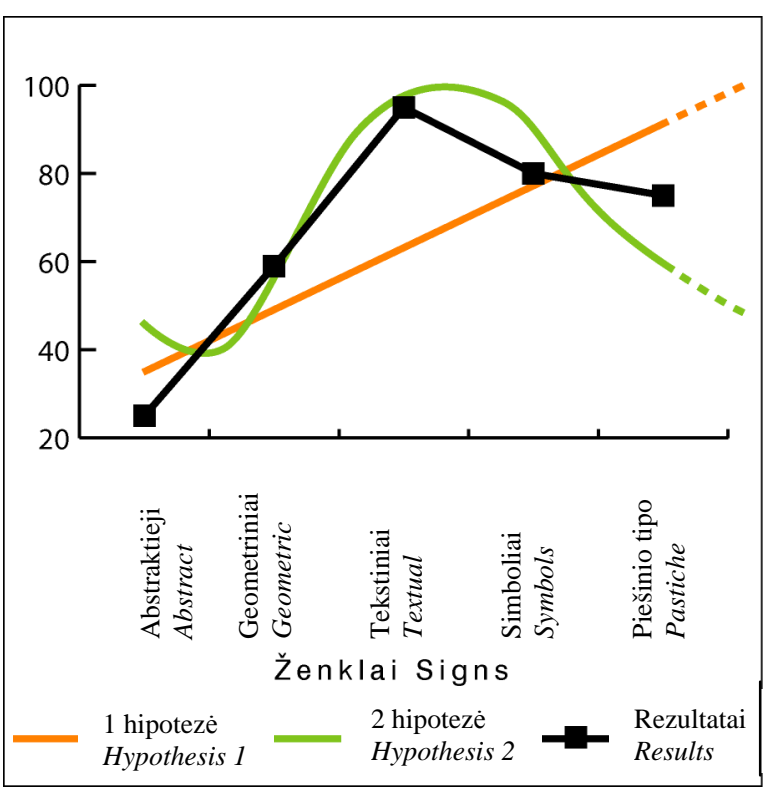

6 pav. Dviejų ženklų atpažinimo hipotezių ir tyrimo rezultatų palyginimas

Fig 6. Comparison of two sign recognition hypotheses and the results of the investigation 
Galima teigti, kad statistiškai pasitvirtino antroji hipotezè, ir geriausiai atpažistami vidutinio asociatyvumo laipsnio ženklai. Taigi turistiniuose žemèlapiuose, siekiant efektyvumo, vietoje populiariu vaizdžiu ženklu tikslingesni tekstiniai ir grafiniai simboliai. Tik reikia pabrěžti, kad simboliai labai susiję su naudotoju ypatumais, ir negalima tikètis, kad neiprasti, svetimi simboliai bus efektyviai įsimenami ir atpažistami.

Atliktas tyrimas nèra išsami studija, nes apibendrinant atpažinimo rezultatu priklausomybę tarp amžiaus ir lyties bei ženklo tipo neatsižvelgta i daug kitu svarbių, nors ir sunkiai i̇vertinamu, veiksnių, pavyzdžiui, ị: turistinių žemèlapių naudojimo dažnumą ir kiekvieno konkretaus respondento patirti, kiekvieno ženklo santykini dažnumą Lietuvoje leidžiamuose turistiniuose žemélapiuose, tą pati objektą žyminčiu ženklu ivvairovę ir t. t. Tai tik bandomasis tyrimas, rodantis, kad yra statistiškai patikimu metodų, kuriais galima i̇vertinti ir patikrinti skirtingo tipo ženklu tinkamumą naudoti îvairios paskirties žemèlapiuose.

Gautais rezultatais gali būti remiamasi sudarant žemèlapius, teminei informacijai vizualizuoti parenkant žemèlapio skaitytojams geriau atpažistamus ženklus; bandomojo tyrimo patirtimi galima remtis ateityje atliekant panašius tyrimus, kurie atspindètu ivvairiu visuomenès grupių žemèlapiu suvokimo ypatumus ir poreikius.

\section{Išvados}

Ištyrus, turistiniuose žemėlapiuose naudojami ženklai suklasifikuoti ì penkias grupes. Tai: abstraktieji, geometriniai, tekstiniai, ženklai-simboliai ir piešinio tipo ženklai. Remiantis šia klasifikacija ivvertintas asociatyvumo (grafinio panašumo į žymimą objekta) ir potencialaus informatyvumo santykis. Statistiniais metodais nustatytas ženklo greito atpažinimo galimybès „lǔžio“ taškas, reiškiantis, kad asociatyvumui viršijus tam tikrą lygi, ženklų suvokimas ne gerèja, bet palaipsniui mažèja, mažèjant jų informatyvumui.

Teoriniu prielaidu pagrindu parengta hipotezè buvo patikrinta statistiškai skirtingose vartotojų grupèse ir pasitvirtino reikšmingu lygmeniu, $p<0,001$. Galima daryti prielaida, kad ji teisinga ir bendruoju atveju.

Universaliuosiuose turistiniuose žemėlapiuose rekomenduojama išlaikyti optimalią priklausomybę tarp ženklo vaizdumo ir galimo informatyvumo. Tam labiausiai tinka vidutinio asociatyvumo laipsnio ženklai. Labai sudètingiems ir i žymimą objektą vizualiai panašiems ženklams didelis funkcionalumas nebūdinga.

Šiuo atveju nagrinètas tik ženklų atpažinimas. Yra ir kitu ženklo pragmatikos aspektu, be to, ženklai paprastai esti susiję su kontekstu, erdvinèmis struktūromis, laikotarpio „mada“ ir kt. Išsamesni tyrimai šia kryptimi leistu sukurti pagristesnę kartografinių ženklu pragmatikos koncepcija, kuria remiantis galima būtu parengti konkrečiu žemèlapiu ženklų sistemų sudarymo metodikas.

\section{Literatūra}

1. Vostokova, A.; Košel, S.; Ušakov, L. Computer aided maps design. Moscow, 2002, p. 23, 40 (in Russian).

2. Berliant, A. Cartography. (Картография) Moscow: Aspekt Press, 2002, p. 73-75 (in Russian).

3. Dumbliauskiene, M. Basics of cartographic communication. Vilnius, 2002, p. 17-21 (in Lithuanian).

4. Fiske, J. Introduction into communication studies (Ivadas i komunikacijų studijas). Vilnius: Baltos lankos, 1998, p. 57-61 (in Lithuanian).

5. Robinson, A.; Morrisson, J. et al. Elements of Cartography. NY: John Wiley and Sons, 1995. 479 p.

6. MacEachren, A. How maps work. Representation, visualization and design. Pennsylvania State University, 1995, p. 218-222.

7. Sluter, R. New theoretical research trends in cartography. Revista Brasileira de Cartografia, No 53, 2001, p. 29-37.

8. Kardelis, K. Methodology and methods of scientific investigations (Mokslinių tyrimų metodologija ir metodai). Kaunas: Judex, 2003, p. 323-325 (in Lithuanian).

9. Čekanavičius, V.; Murauskas, A. Statistics and its applications, part II (Statistika ir jos taikymai, II dalis). Vilnius: TEV, 2002, p. 48-75 (in Lithuanian). 